\title{
Inbound Marketing Strategy: Marketing Concept To Increase Sales of Small and Medium Enterprises (SMEs) Products in Indonesia
}

Tommy Pusriadi, Sudarmiatin

To Link this Article: http://dx.doi.org/10.6007/IJARBSS/v11-i5/9888

DOI:10.6007/IJARBSS/v11-i5/9888

Received: 04 April 2021, Revised: 26 April 2021, Accepted: 13 May 2021

Published Online: 28 May 2021

In-Text Citation: (Pusriadi \& Sudarmiatin, 2021)

To Cite this Article: Pusriadi, T., \& Sudarmiatin. (2021). Inbound Marketing Strategy: Marketing Concept To Increase Sales of Small and Medium Enterprises (SMEs) Products in Indonesia. International Journal of Academic Research in Business and Social Sciences, 11(5), 730-736.

Copyright: (c) 2021 The Author(s)

Published by Human Resource Management Academic Research Society (www.hrmars.com)

This article is published under the Creative Commons Attribution (CC BY 4.0) license. Anyone may reproduce, distribute, translate and create derivative works of this article (for both commercial and non-commercial purposes), subject to full attribution to the original publication and authors. The full terms of this license may be seen at: http://creativecommons.org/licences/by/4.0/legalcode

Vol. 11, No. 5, 2021, Pg. 730 - 736

Full Terms \& Conditions of access and use can be found at http://hrmars.com/index.php/pages/detail/publication-ethics 


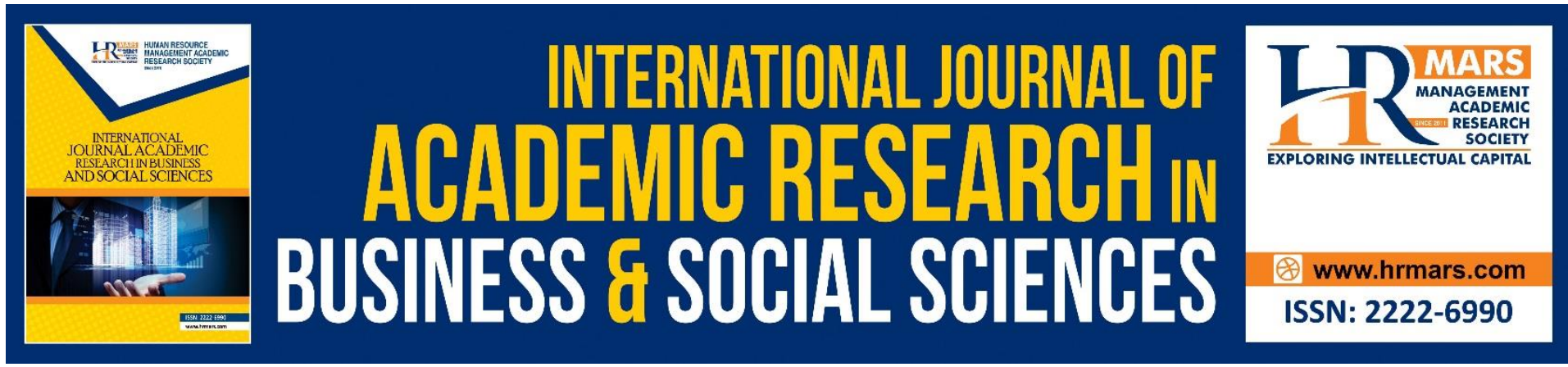

\title{
Inbound Marketing Strategy: Marketing Concept To Increase Sales of Small and Medium Enterprises (SMEs) Products in Indonesia
}

\author{
Tommy Pusriadi, Sudarmiatin \\ Postgraduate Program Doctoral Faculty of Economics, Universitas Negeri Malang- \\ Indonesia. \\ Email: tommy.pusriadi.2004139@students.um.ac.id, sudarmiatin.fe@um.ac.id
}

\begin{abstract}
This article aims to overview Small and Medium Enterprises (SMEs) to adopt the concept of inbound marketing to be applied to their business. Article writing is obtained by studying literature from a variety of reputable and reliable sources. The literature study results found there are four phases in applying the concept of inbound marketing, namely Attracting visitors, Converting visitors to leads, Closing Sales, and Reconverting customers to loyal lifelong customers and brand promoters that are all possible to be applied by all SMEs. The hope of writing this article is that more SMEs will be able to quickly adopt the concept of inbound marketing that will make the marketing of SMEs products more effective and efficient, especially during the Covid19 pandemic.
\end{abstract}

Keywords: Inbound Marketing, Outbound Marketing, SMEs, Covid19

\section{Introduction}

The development of internet users in Indonesia in the last ten years has experienced significant growth. As of 2021, of Indonesia's 274.8 population, there are 202.6 million internet users, which will grow by $15.5 \%$ from 2020. Meanwhile, 170 million Indonesians will be active on social media by 2021 , or $61.8 \%$ of Indonesia's population (Hootsuite, 2021).

The covid19 pandemic requires all world communities to maintain distance or social distancing. This condition has forced various activities to be done in a very limited and not accessible face-to-face. The world economy simultaneously experienced a slowdown characterized by the economic growth of almost all countries experiencing a decline and decreased business activity. This situation has encouraged businesses to change their business patterns and activities in different ways. Maximum utilization of digital technology for the sustainability of the business world. This condition gives the company a lot of experience. At the same time, all retail companies have accelerated the digital transformation that implies a "new player" in the online market (Erdmann \& Ponzoa, 2021).

The development of marketing strategies has undergone a significant evolution, the existence of digital communication and social networks, the creation of marketing content undergoes significant changes. In this era, there is a shift in approach to consumers made by companies. Traditionally the marketing process is done aggressively through outbound 
marketing; nowadays, inbound marketing practices have been widely applied as a new concept in marketing. Outbound marketing is a marketing model that encourages marketing messages to reach as many people as possible through various ways and media, such as advertising, SMS blast, to telemarketing.

Outbound marketing is considered less effective and efficient because it targets as many people as possible without considering the interest in their message goals to cause people to feel disturbed, and in terms of costs are also very large. Outbound marketing is a disruptive way people are distracted from interacting with products where traditional marketers have a job pushing products to potential targets or customers (Opreana \& Vinerean, 2015).

This research hopes that this research can help SMEs start and consistently implement inbound marketing as an effective and efficient marketing strategy. SMEs actors are the time to carry out a low-cost and targeted marketing strategy to not waste too much time, effort, and cost.

\section{Related Literature}

The idea behind inbound marketing is how to implement marketing strategies to increase interest and entice people to visit the company's website rather than doing promotions with ads that can be annoying (Bezhovski, 2015). Inbound marketing is permission-based marketing because messages are focused on a target audience that has previously permitted to communicate, while outbound marketing is distraction-based marketing, considered a traditional model of product promotion, where people have to stop what they are doing to pay attention to marketing messages or handle them in other ways (Rancati et al., 2015).

Outbound marketing implements ads traditionally that have been very saturated where hundreds of brands compete and compete to get customers' attention. When advertising is over, it will be challenging to stand out from competition and growing promotional costs (Lehnert et al., 2020). In contrast to Inbound marketing, which focuses on creating and sharing content which is a marketing methodology to be discovered by prospects through blogs, podcasts, eBooks, e-newsletters, website pages, search engine optimization (SEO), social media marketing, and other forms of content marketing (Soegoto \& Simbolon, 2018). Inbound Marketing is a combination of various digital elements that can attract customers efficiently on marketing activities in the company (Bueno et al., 2018).

Inbound marketing is a collaboration of various digital marketing concepts that require collaboration and intelligence to overcome challenges where in the future, competition pressures will be higher (Sánchez-Teba et al., 2020). In today's fast-paced market, the Internet and social networks influence consumers' daily decisions. Due to the open-source nature of the Internet and the billions of users joining the network every day, customers are currently exposed to more information than ever before (Patel \& Chugan, 2018).

The difference in activity between inbound marketing and outbound marketing is shown in the table.1: 
Table 1. Activity differences between inbound marketing and outbound marketing

\begin{tabular}{|c|c|c|}
\hline & Inbound marketing & Outbound marketing \\
\hline Basic & Permission-based/organic & Interruption based \\
\hline Purpose & $\begin{array}{l}\text { Create long-term relationships by } \\
\text { reaching out and converting quality } \\
\text { consumers }\end{array}$ & Increased sales \\
\hline Focus & $\begin{array}{l}\text { Discovered by potential } \\
\text { consumers. }\end{array}$ & Finding consumers \\
\hline Target & Interested prospects & Wide audience \\
\hline \multirow[t]{8}{*}{ Techniques } & Blog, website, e-book & Print media ads \\
\hline & Search engine optimization (SEO) & TV and Radio Commercials \\
\hline & Webinars, Podcast & Outdoor Advertising \\
\hline & Video on Youtube & Exhibition \\
\hline & Social media (Instagram, Facebook, & Email list/ Direct mailing \\
\hline & Twitter, Whatsapp, etc. & Direct advertising \\
\hline & Content marketing & \\
\hline & Electronic Word-of-mouth (eWOM) & \\
\hline Cost & Relatively low cost & Requires a high-cost budget \\
\hline
\end{tabular}

Source: Opreana and Vinerean, (2015); Rancati et al., (2015)

The differences in the application of inbound marketing and outbound marketing strategies, according to Sánchez-Teba et al. (2020), are shown in table 2.

Table 2. Differences in the application of strategic inbound marketing and outbound marketing

\begin{tabular}{ll}
\hline Future & Past \\
\hline Inbound marketing does not replace & Companies with considerable resources \\
conventional advertising but complements & should not overlook the benefits of reaching \\
it from the digital world. & a wider audience through Outbound \\
& marketing.
\end{tabular}

Inbound marketing tries to create unique The outbound marketing methodology valuable content focuses on high conversion rates and broad brand exposure through advertising in print and other media types. Outbound marketing can help generate trust among potential visitors, as all traditional methodologies will bring the goal closer to potential visitors to achieve the higher level of trust required after the pandemic

In SMEs, businesses that have budget constraints do not have to be all techniques of inbound marketing applied. SMEs actors can choose only a few that suit the needs and conditions of the company. It is necessary to carefully consider the selection of the proper techniques to achieve the goal. Some methods that SMEs can use are:

1. A blog is a website that contains unique content in the form of articles, videos, photos, and links to other websites provided by the blog's author. MSME actors can create blogs at a 
low cost, and nowadays, many website creation services at low cost such as WordPress, can be used to create a variety of websites, from online stores to corporate websites.

2. Video on Youtube is a video-sharing website about what is easily accessible to anyone. SMEs actors can create Youtube channels easily.

3. Social Media is a digital technology that utilizes an internet network that can be easily operated to share news, images, videos, data, and location. SMEs actors can use social media networks such as Instagram, Facebook, Whatsapp, Twitter, etc., as a tool in carrying out their marketing strategies and activities.

4. Content marketing uses high-quality and relevant content to educate, engage, and acquire target customers (Ramos, 2013). The true potential of content marketing lies in its ability to provide conversion paths for prospects to follow their schedules and at their convenience.

5. Podcasts are a broadcasting activity that utilizes Youtube channels to be watched by many people. Podcasts are usually a casual chat by anyone with light to heavy themes. Celebrities and influencers today do podcast activities for various purposes. SMEs actors can do podcasts to build a brand, discuss products or entertain with insert promotion.

6. Search engine optimization (SEO) is a series of systematic processes to increase visits to certain websites by utilizing algorithms. With only keywords, certain websites will appear at the top or on the main page of search engines such as Google. SEO (Search Engine Optimization) is based on the assumption that organic traffic (free traffic, no ads in the media) of the site depends on its natural reference quality, so that search engines (including Google) can find it and mainly list keywords correctly (Dakouan \& Benabdelouahed, 2019). The system must be paid within a specific time. SMEs who have a sufficient budget can use SEO as a means for consumers to find their websites quickly.

7. Webinars are seminars, workshops, training, counseling activities by utilizing teleconference applications. The Covid 19 pandemic where all the inhabitants of the earth are required to keep their distance has made webinars popular and widely used by people to do seminar activities, education, education, and others. SMEs actors can create webinars with exciting themes of the potential constituency. This method is quite effective and cheap.

\section{Method and Measurement}

Four stages of inbound marketing that SMEs and other businesses can apply:

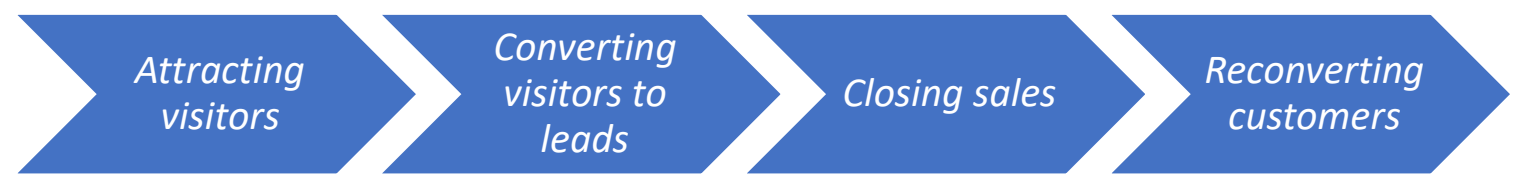

Fg 1. Source: (Woodard, 2016)

1. Attracting visitors, at this stage, the main focus of the business is attracting attention. This stage is done to make prospective customers who have not known about the brand so that they know. The attraction phase plays an essential role in the inbound marketing methodology to attract a specific target audience. The content created must be appropriate and reach many people Sánchez-Teba et al., (2020). Some practices that can be used to attract the attention of prospective consumers are Content marketing, SEO, 
Digital Advertising, and Social media marketing. This phase not only showcases the product but, more importantly, is a high-value offering for consumers.

2. After successfully attracting the attention of potential consumers and becoming followers, converting visitors to leads should turn them into leads, i.e., people who have the potential to buy. Therefore, it is necessary to get their contact information, such as email address, mobile number / Whatsapp, Instagram account, and the like. With contact information, it will be an opportunity to contact potential customers personally. Not only to build relationships but also to attract them to make purchases.

3. After successfully obtaining a contact number or social media account, closing sales can be made by sending content or messages to make them interested in buying. In addition to content or letters can also be given a purchase discount offer.

4. Reconverting customers to loyal lifelong customers and brand promoters, because consumers who make purchases are interested in the business or products offered, then inviting them to buy again will not be as difficult to pursue new consumers. Email marketing can be done to build relationships with them by creating surveys to ensure customer satisfaction. Good interaction will also open the opportunity to provide information related to the advantages of the product and a way out for customers to submit complaints or complaints about the products they have purchased. So, good interaction will make customers feel satisfied and make them loyal.

The four stages of inbound marketing can be applied to various SMEs businesses in Indonesia. The success of an inbound marketing strategy is strongly influenced by the willingness and high willingness to implement it to achieve the goal truly. Many SMEs in Indonesia have not been disciplined and focused on running their business operations. Attracting customers through the Internet and social media today is quite heavy and challenging because almost all SMEs have utilized social media to market their products. Creativity and continuous innovation are needed in managing social media to continue to be a concern for customers.

\section{Conclusion}

The increasing growth of the internet and social media users in Indonesia opens up great opportunities for businesses to conduct effective and low-cost marketing. SMEs now realize that outbound marketing efforts alone are not enough to increase sales and generate profitability. Therefore, inbound marketing techniques are needed to attract more leads and foster better brand preferences. Inbound marketing relevant to the financial condition of MSMEs during the covid19 pandemic, where inbound marketing is much more budgetefficient for marketing.

To succeed in inbound marketing, SMEs and other small businesses need a disciplined approach to content creation, adding marketing automation tools that can help them nurture and print leads and optimize how these leads flow through the sales funnel for continued business success and growth.

The results of this paper contributed significantly to the theory of science in the field of marketing strategy, where the theories in inbound marketing are very following the era of digitalization as it is today. Some marketing strategy theories are no longer relevant to the development of the times. Industrial Revolution 4.0 demands readiness from all sectors to digitize by utilizing the internet network. Including the field of marketing that has an essential role in the development of the business. In the context of SMEs, inbound marketing is very appropriate to be applied to the SMEs sector because in principle inbound marketing emphasizes to be effective and efficient in marketing strategies. 


\section{References}

Bezhovski, Z. (2015). Inbound Marketing-a New Concept in Digital Business. SELTH 2015 International Scientific Conference of the Romanian-German University of Sibiu, Constantinides 2002, 1-8.

Bueno, S., Caro Rodríguez, J. S., \& Gallego, M. D. (2018). Inbound Marketing to improve interest in public postgraduate courses. ESIC MARKET Economic and Business Journal, 49(3), 533-550. https://doi.org/10.7200/esicm.161.0493.3i

Dakouan, C., \& Benabdelouahed, R. (2019). Inbound Marketing vs. Outbound Marketing: Independent or Complementary Strategies. Expert Journal of Marketing, 7(1), 1-6.

Erdmann, A., \& Ponzoa, J. M. (2021). Digital inbound marketing: Measuring the economic performance of grocery e-commerce in Europe and the USA. Technological Forecasting and Social Change, 162(June 2020), 120373.

https://doi.org/10.1016/j.techfore.2020.120373

Hootsuite. (2021). Digital 2021 Indonesia (January 2021) v01.

https://www.slideshare.net/DataReportal/digital-2021-indonesia-january-2021-

v01?qid=3a1d3777-02dd-49a0-b004-fe0d181f4558\&v=\&b=\&from_search=9

Lehnert, K., Goupil, S., \& Brand, P. (2020). Content and the customer: inbound ad strategies gain traction. Journal of Business Strategy, 42(1), 3-12. https://doi.org/10.1108/JBS-122019-0243

Opreana, A., \& Vinerean, S. (2015). A New Development in Online Marketing Introducing Digital Inbound Marketing. Expert Journal of Marketing, 3(1), 29-34.

Patel, C. P., \& Chugan, P. K. (2018). Digital Inbound Marketing to Drive the Success of Startups. International Journal of Family Business and Management, 2(1), 1-6. https://doi.org/10.15226/2577-7815/2/1/00111

Ramos, R. (2013). Content Marketing: Insider's Secret to Online Sales and Lead Generation (1st ed.). One Night Expert Publishing.

Rancati, F., Capatina, A., Dunarea, U., \& Galati, D. J. (2015). Inbound and Outbound Marketing Techniques: a Comparison Between Italian and Romanian Pure Players and Click and Mortar Companies. Risk in Contemporary Economy, 2(1), 232-238.

Sánchez-Teba, E. M., García-Mestanza, J., \& Rodríguez-Fernández, M. (2020). The application of the inbound marketing strategy on costa del sol planning \& tourism board. Lessons for post-covid-19 revival. Sustainability (Switzerland), 12(23), 1-15. https://doi.org/10.3390/su12239926

Soegoto, E. S., \& Simbolon, T. (2018). Inbound Marketing as a Strategy in Digital Advertising. IOP Conference Series: Materials Science and Engineering, 407(1). https://doi.org/10.1088/1757-899X/407/1/012183

Woodard, R. (2016). Why Macklemore is the Inbound Marketing Master. https://9clouds.com/blog/macklemore-inbound-marketing-master/ 